\title{
Japan's E. coli genome project falling short
}

Tokyo. A pioneering effort launched by Japan in 1989 to sequence the complete genome of the bacterium Escherichia coli is still far short of its goal, and now lags behind two more recent international efforts, led by European scientists, to sequence the genomes of the bacterium Bacillus subtilis and yeast.

At the start of the $E$. coli project, its Japanese leaders said they hoped to complete the identification of the 4,700 kilobases of the genome in about five years (see Nature 338, 283; 1989). But an international symposium on large-scale DNA sequencing held in Tokyo earlier this month was told that only 274 kilobases have so far been sequenced. Another 500 kilobases have been sequenced by a US group at the University of Wisconsin, while many other $E$. coli sequences are scattered in databases around the world.

In contrast, the $B$. subtilis project, initiated by a consortium of five European laboratories in September 1989 and partially backed by the European Commission in Brussels, has sequenced about 900 kilobases, including 500 kilobases by seven Japanese laboratories.

Similarly, a recent worldwide effort led by Europe to sequence the yeast genome, and involving scientists in Europe, the United States, Japan and Canada, has already completed more than 2,000 kilobases of four yeast chromosomes (III, XI, II and VI). The symposium was also told that the whole yeast genome of 12,800 kilobases may be completed by 1997 .

The Japanese $E$. coli project was given a special "priority" grant of several million dollars over a period of three years by the Ministry of Education, Science and Culture (MESC). But at the time it was launched, many scientists were still "cold" to the idea of systematic sequencing of genomes, says Katsumi Isono of Kobe University, one of the project's leaders.

As a result, says Isono, Japan was unable to win international participation. "Perhaps we did not push rigorously enough," he admits.

Another reason sequencing projects attracted little support among young researchers in Japan was that they feared they would be required to carry out the work of technicians. Furthermore, although about 30 Japanese researchers participated in the project during the three years of the priority grant, many did not do sequencing.

European scientists at the symposium offered two explanations for not participating in the Japanese project. One was that two US groups announced in 1987 that they intended to sequence the whole $E$. coli genome in two years, a move that deterred the formation of an E. coli project in Europe.

In addition, many European scientists felt that, given the number of individuals working on $E$. coli worldwide, and the fact that many of its genes had been sequenced, a special project was not needed to complete the sequencing.

Another factor hampering the Japanese project was the rigid set of rules governing the use of grants awarded by the ministry of education. Unlike US and European government grants, Japanese government grants cannot be used to employ full-time personnel, such as technicians and postdoctoral fellows. As a result, the Japanese group was unable to train and then keep people with the

technical skills needed to carry out a longterm sequencing project.

After the priority grant ended in 1992, the project struggled along with a small grant awarded to a researcher at Tokyo University, which ends this month. Despite the setbacks, the project leaders are still hoping to win another "priority" grant next year, and they plan to subcontract much of the sequencing work to private companies. They also still hope that European scientists will join the project.

David Swinbanks

\section{Regional Cinderellas ask for more}

London. Figures published by the British government last week seem likely to reignite a long-standing campaign by scientists in Wales and Northern Ireland for more money to be spent on scientific research in outlying regions of the United Kingdom.

The figures for the regional distribution of funds spent by the five British research councils reveal that whereas Wales and Northern Ireland have respectively 5.0 and 3.0 per cent of the British population, they account for only 3.7 and 0.6 per cent of the total research council expenditure.

For some research councils, the difference is even sharper (see figure). The Sci-

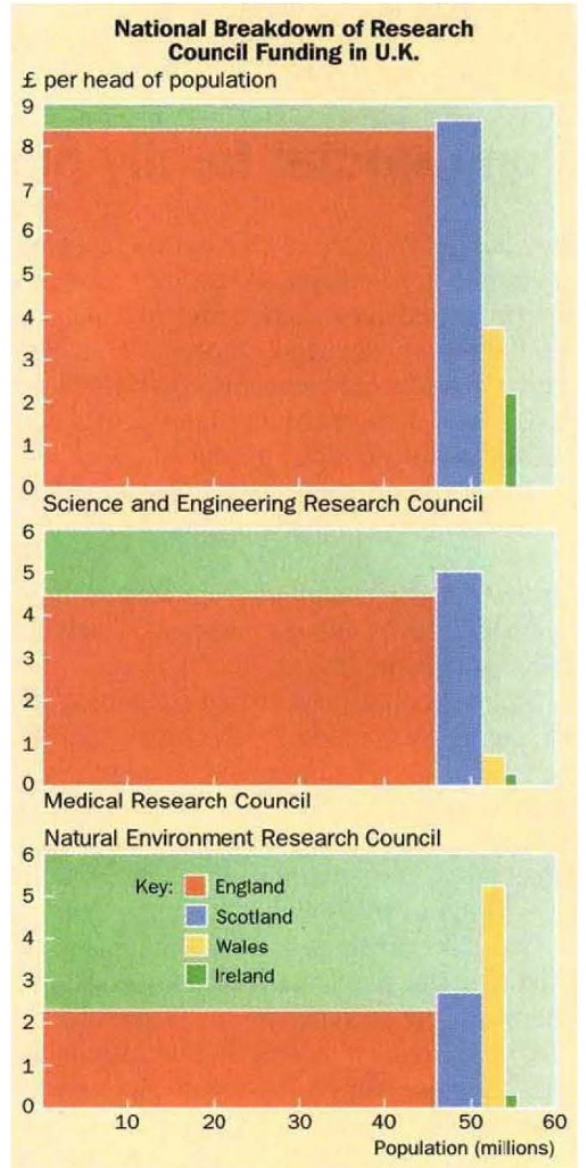

ence and Engineering Research Council, for example, spends $£ 8.3$ per head of population in England (and $£ 8.6$ in Scotland), but only $£ 3.75$ in Wales and even less in Northern Ireland.

Research council officials explain the disparities by saying that the distribution of research grants is determined by scientific merit and by historical factors that have led to the creation of facilities at or close to major research universities in England.

But some researchers complain that present policies underplay the value of government-funded research institutions in stimulating economic development, a factor widely recognized elsewhere in Europe and in the United States. "As far as I can tell, economic and regional factors have never been taken seriously in deciding where to establish major research institutions," says Phil Williams, professor of physics at the University of Wales at Aberystwyth.

Williams, a plasma physicist, says that countries as different in their political traditions as Sweden and the United States have located major astronomy facilities in depressed mining areas (Koruna and Greenbank, Virginia, respectively). He claims the British government has never acted similarly.

The regional distribution of British funds was made public last week by David Davies of the Office of Science and Technology in response to a parliamentary question from Cynog Dafis, Plaid Cymru member of parliament for the Welsh constituency of Ceredigion \& Pembroke North.

The figures have been seized upon by Welsh nationalists, who say that research council spending should be integrated into regional policy. This pressure is likely to figure prominently in nationalists' campaigns in the elections to the European Parliament this June. Dafydd Williams of Plaid Cymru's political liaison office in London says that past practice on the siting of research establishments amounts to imposing "a reverse regional policy by default".
David Dickson 